\title{
New health minister doesn't mean new regime, say experts
}

$\mathrm{C}$ anada has a new federal health minister, but some industry pundits don't think a change of face will mean a change in regime.

Rona Ambrose replaced Leona Aglukkaq as health minister on July 15 as part of Prime Minister Stephen Harper's cabinet shuffle.

Ambrose, 44, is the former minister of public works and has been a member of Parliament (Edmonton-Spruce Grove) since 2004, holding diverse portfolios including environment, intergovernmental affairs, labour, western economic diversification and status of women. As minister for the status of women, Ambrose played a significant role in launching the Women's Brain Health Initiative, an Alzheimer disease research think tank.

Although some Canadian health care advocates have expressed optimism about the new minister, their general outlook on the shuffle is cynical.

"We really see a shuffling of the deck, but the cards are all the same," said Adrienne Silnicki, health care campaigner for the Council of Canadians, a social action organization with 60 chapters across Canada.

"The prime minister does not let most ministers make independent decisions about policies," said Dr. Michael Rachlis, a leading health care analyst at the University of Toronto, Ont. "She (Ambrose) will be judged mainly on

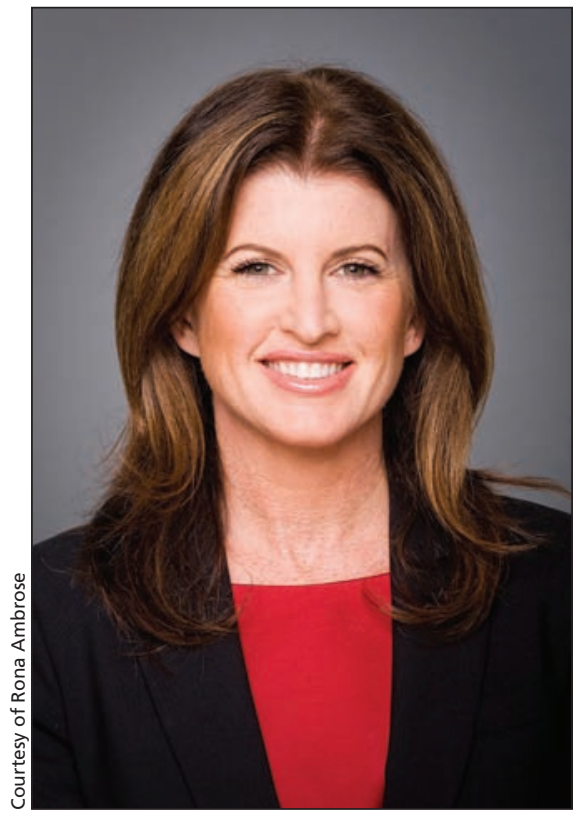

Rona Ambrose replaced Leona Aglukkaq as health minister on July $\mathbf{1 5}$ as part of Prime Minister Stephen Harper's cabinet shuffle.

her ability to keep a lid on any issues that could get hot."

On the minds of many is the 2004 health accord, which expires next year. In lieu of a renewed health accord, the federal government has changed its transfer calculations. Transfers will increase by $6 \%$ per year until the 2017/18 fiscal year, when increases will be tied to economic growth.

A number of health care advocates, including the Council of Canadians and the Canadian Health Coalition, have seen this as too hands-off and want the government to establish and monitor national health care standards.

"If renewing the health care system is not in her (Ambrose's) mandate, then she will be presiding over the dismantling of the national standards in medicare," says Michael McBane, national coordinator at the Canadian Health Coalition, a public advocacy organization dedicated to the preservation and improvement of medicare. "It would be quite the legacy."

McBane says he will remain optimistic, however. "We are hopeful that the new minister will at least be open and sit down and listen and get input from the supporters of the national health care system."

In an email sent through her press secretary, Ambrose emphasized the government's commitment to "long-term, stable funding" and health research.

"I have reached out to all of my provincial and territorial colleagues about their priorities in health care and shared with them my commitment to working together," Ambrose stated. "We are committed to preserving Canada's strong public healthcare system through our investments and transfers to the provinces and territories." Catherine Cross, CMAJ

CMAJ 2013. DOI:10.1503/cmaj.109-4562 